\title{
Po obu stronach Śródziemnomorza, czyli o podróżowaniu i jego kontekstach kulturowych
}

DOI: http://dx.doi.org/1 0.12775/LC.2019.001

\section{$\mathbf{P}$}

odróże kształcą - czyż można rozpocząć tom o podróżach innym niż to wyświechtane, ale jakże zawsze aktualne powiedzenie? O tym zresztą świadczą wszystkie zamieszczone tutaj teksty, ale one niech mówią same za siebie. Zaświadczają bowiem z pewnością, jak ważnym elementem każdej kultury na każdym etapie jej rozwoju jest podróż.

Podróże kształcą ludzi wszystkich epok i wszystkich obszarów. W tym wstępie wypada skoncentrować się na paradygmacie podróży, pojmowanym zresztą bardzo szeroko, przede wszystkim w kulturze arabsko-muzułmańskiej. Bo to podróże do świata arabskiego i podróże Arabów głównie do Europy są osią zamieszczonych tu tekstów. Jeden z artykułów opublikowanych kilka lat temu współautor tego wprowadzenia zatytułował Choć się nie znamy, znamy się od dawna (Dziekan 2012: 135-157). I tak można podsumować efekty podróży odbywanych przez Arabów do Europy i Europejczyków do świata arabskiego. Podróże kształcić powinny, ale czy czynią tak rzeczywiście? Czy sprawiają, że ludzie różnych kultur lepiej się poznają? A jeśli poznają, to czy czynią z tego odpowiedni pożytek? Tu znów odwołamy się do opracowań zawartych w tym tomie - niech Czytelnik sam na te pytania odpowie.

W kulturze arabskiej podróż ma rozmaite aspekty. Wieczna wędrówka, wieczna podróż charakteryzowała cywilizację Półwyspu Arabskiego od samych jej początków - została przecież stworzona przez koczowniczych beduinów, którzy rzadko zagrzewali gdziekolwiek miejsce. Poezja staroarabska jest przepełniona opisami podróży przez pustynię. $\mathrm{Na}$ rączej wielbłądzicy wędrowano w poszukiwaniu wody, z towarami na kolejny targ albo z pielgrzymką do Mekki czy innego świętego miejsca. A zatem miała podróż także aspekt sakralny, nie tylko użytkowy. Staroarabska typowa kasyda to często wiersz o wędrówce np. do króla czy innego władcy, któremu poeta chciał ofiarować swój poemat.

Wkraczając już w świat naznaczony islamem, warto wspomnieć, że o podróżach w celach handlowych mówi Koran $(106,2-3)^{1}$, zalecając także podróże w poszukiwaniu doświadczeń: „Wędrujcie po ziemi, potem popatrzcie, jaki był ostateczny koniec tych, co za-

1 Cytaty z Koranu według przekładu Józefa Bielawskiego. 
przeczali prawdzie!” $(6,11)$. Bez podróży nie byłoby arabskiej cywilizacji beduińskiej, albo byłaby ona całkiem inna. Trzeba jednak podkreślić, że były to podróże lądowe. Na wybrzeżach Morza Czerwonego oraz na wschodzie Półwyspu funkcjonowały wprawdzie porty, jednak na kulturze podróże morskie nie wywarly znaczniejszego piętna. Przysłowiowym podróżnikiem staroarabskim stał się poeta Al-A šà, lecz podróże starożytnych Arabów nie wskazują na ich zbytnie zainteresowanie światem zewnętrznym, tak jak świat zewnętrzny nie interesował się nimi, choć obie strony miały doskonałą świadomość wzajemnego istnienia.

Inny religijny czynnik podróżowania ucieleśnia Prorok Muhammad, który był kupcem, co wiązało się m.in. z podróżami, stąd imitatio Muhammadi skłaniało muzułmanów do podróżowania. W jednym $\mathrm{z}$ hadisów Prorok powiedział: „Szukajcie wiedzy choćby w Chinach", a przecież zdobywanie wiedzy w Chinach siłą rzeczy musiało wiązać się z podróżami. Stąd popularne były w kulturze arabsko-muzułmańskiej podróże fĩ țalab al-'ilm 'w poszukiwaniu wiedzy'. $Z$ czasem podróże stały się istotnym elementem procesu transmisji wiedzy w islamie.

Niewątpliwie istotną rolę w rozwoju muzułmańskiej „turystyki” średniowiecznej miały pielgrzymki do Mekki - każdy przecież wyznawca islamu powinien raz w życiu odwiedzić mekkańskie sanktuarium (por. Hammoudi 2008).

Ściśle związana z podróżą droga - w rozmaitych aspektach - zadziwiająco często pojawia się w arabskiej terminologii dotyczącej różnych dziedzin. I tak - sunna to etymologicznie 'droga, ścieżka'; madhab (szkoła prawa, także odłam religijny) - 'droga'; țaīqa 'droga'; wreszcie naḥw (gramatyka) - 'wytyczony szlak', podobnie jak nahğ (w Maghrebie to słowo funkcjonuje w znaczeniu 'ulica'), a šari'a - 'droga do wodopoju' - od tego samego rdzenia pochodzi także współczesne, najbardziej rozpowszechnione określenie ulicy - šāri . A zatem podróż - można by ją określić jako „duchową” - naznacza całe właściwie życie Araba-muzulmanina.

To naznaczenie podróżą przyczyniło się z pewnością do tego, że w obrębie literatury geograficznej rozwinęła się w piśmiennictwie muzułmańskim literatura podróżnicza adab ar-rihlāt. Co jednak ciekawe, podróże Arabów na wschód, zachód czy południe miały w głównej mierze charakter poznawczy i nie wiązały się zazwyczaj z rozpoznaniem terenu, aby go później podbić, co było dość charakterystyczne dla podróży podejmowanych przez Europejczyków. Z biegiem czasu jednak chęć Arabów do podróżowania malała.

Pierwsze zachowane choćby we fragmentach arabskie opisy podróży pochodzą z drugiej połowy VIII wieku. Najczęściej były to teksty pisane na zamówienie i początkowo nie wyróżniały się zbyt wysokimi walorami literackimi. Te ukształtowały się ostatecznie w X wieku. W tymże czasie działali również As-Sīrāfī i Buzurg Ibn Šahriyār². Charakterystycznym gatunkiem podróżniczej literatury arabskiej jest rị̣la, „podróż” właśnie, ale rozwinęła się ona nieco później (za jej twórcę często bywa uważany Andaluzyjczyk Ibn Ğubayr, zm. 1217) i swój okres klasyczny przeżywała nie na Wschodzie, lecz na Zachodzie świata arabskiego, a jej najwybitniejszym przykładem jest Rihla Ibn Batțūty (XIV wiek) ${ }^{3}$, nazywanego „arabskim Marco Polo”. Warto zresztą w tym miejscu zwrócić uwagę, że podróżowali oni mniej więcej w tym samym czasie, a ich dzieła, z punktu widzenia geografii, uzupełniają

\footnotetext{
2 Szerzej na temat tych postaci i ich twórczości por. Zaborski 1998.

3 Polski przekład wybranych fragmentów w Ibn Battuta 2008.
} 
się. Marco Polo opisał obszary, na które nie dotarł Ibn Bațtūṭa, ale całościowa lektura ich przekazów (oczywiście z uwzględnieniem bezsprzecznie innego punktu widzenia - chrześcijanina i muzułmanina) dają nam szeroką panoramę świata znanego ówczesnej cywilizacji śródziemnomorskiej.

Obok relacji z rzeczywistych podróży wielkim powodzeniem cieszyła się tzw. literatura 'ăğa 'ib - czyli 'cudów', gdzie autorzy opisywali nieistniejące morza, lądy, ludy i rozmaite stworzenia. Tutaj pierwszeństwo należy się również Andaluzyjczykowi z XII wieku, Abū Hāmidowi al-Ḡarnāțiemu (2006), ale najdoskonalszym przykładem tego typu literatury pozostają Cuda stworzeń Al-Qazwīniego (XIII wiek) (Bieniek 2002). W tym nurcie pozostają też lepiej znane Europie opowieści Sindbada Żeglarza. Całkiem odrębnym zagadnieniem są podróże duchowe czy też fantastyczne, ale niemające na celu stworzenia fikcji udającej rzeczywistość, jak choćby uwzględniona w tym tomie „podróż” Ibn Šuhayda, którą należy oczywiście zestawić z nieśmiertelnym dziełem Dantego. Świadczy to o niezwykłej pojemności kulturowo pojmowanego hasła „podróż”.

Literatura podróżnicza - zarówno ta bardziej „zbeletryzowana”, jak i czysto dokumentalna - stała się ważnym źródłem i dla literatury pięknej, i dla rozwoju naukowej literatury geograficznej. Z kulturowego zaś punktu widzenia poszerzała geograficzny horyzont cywilizacji islamu i kultury arabskiej.

W przypadku piśmiennictwa europejskiego można wskazać na podobne czynniki skłaniające do podróży. Najważniejszym, od czasu utrwalenia się w Europie chrześcijaństwa, były pielgrzymki. I chodzi zarówno o pielgrzymki do miejsc świętych na terenie kontynentu, jak i - ważniejsze tu dla nas - podróże na Wschód - do miejsc związanych z najwcześniejszymi dziejami chrześcijaństwa. Najstarszym takim tekstem jest Peregrinatio ad loca sancta mniszki Eterii z IV wieku (Eteria 1970). W literaturze chrześcijańskiego Wschodu były to tzw. chożdienija (Daniel 2003). Głównym celem tych pielgrzymek stał się oczywiście średniowieczny „pępek świata” naszej cywilizacji - jak to widać wyraźnie na średniowiecznych mapach, czyli Jerozolima (Hauziński 1997: 73-80).

Europejczycy wyruszali na Wschód i zapoznawali się tam nie tylko z miejscami będącymi świętym celem ich podróży, ale także z ówczesnymi mieszkańcami tamtych ziem, dużo wyżej postawionymi cywilizacyjnie Arabami i innymi mieszkańcami Lewantu, bardzo często zbiorczo, choć zwodniczo nazywanymi „Turkami”. Trzeba przy tym przyznać, że nierzadko opisy tych podróży były typowymi itinerariami pątniczymi, a autorzy traktowali żyjących tam ludzi niemal niczym powietrze. Dopiero z czasem uległo to stopniowej zmianie, a Europejczycy zaczęli dostrzegać na Bliskim Wschodzie po prostu ludzi, a nie beznamiętne tło dla miejsc świętych chrześcijaństwa. Dawna literatura europejska zna także koncepcję podróży fikcyjnej, przypominającej arabskie 'ağa' łem są Podróże Jana z Mandeville (2013), które zawojowały XVI-wieczne, jak byśmy to dziś powiedzieli, europejskie rynki wydawnicze.

Wraz ze zmianami historycznymi, społecznymi i politycznymi w basenie Morza Śródziemnego pojawiły się też innego typu opisy podróży - podróży dyplomatycznych, wszelkiego rodzaju misji typowo handlowych. Dla Europejczyków, szczególnie z warstw wyższych, popularne stały się podróże edukacyjne, przypominające w wielu aspektach muzułmańskie wyprawy fí țalab al-'ilm. Zawierały one często istotne opisy i przemyślenia dotyczące życia społecznego i kulturalnego opisywanego świata. W kontekście bliskowschodnim najważniejsza była romantyczna tradycja podróży, ponieważ w ramach ówcze- 
snego „orientalizmu” stały się one częścią sposobu funkcjonowania w obiegu kulturalnym. Warto tu wspomnieć choćby Gérarda de Nervala (1967), a z naszych poetów Juliusza Słowackiego (Przybylski 1982; Słowacki 2009). Podróż miała być bezpośrednim zasmakowaniem Wschodu wyidealizowanego przez nieszczęsną Księgę tysiąca $i$ jednej nocy w wersji Gallandowskiej. Co ciekawe, z całkiem innych powodów dość obfita jest także arabska literatura podróżnicza tegoż okresu. W XIX wieku Arabowie chcieli poznać Europę, ale nie po to, by „okcydentalnych” motywów używać w literaturze pięknej - choć i tak się zdarzało, lecz by zapoznać się z cywilizacyjnymi osiągnięciami kultury zachodniej. Był to bowiem czas, żeby muzułmański Bliski Wschód zmienił swoją rolę z nauczyciela w ucznia ... Porównanie XIX-wiecznych arabskich i europejskich tekstów podróżniczych daje obraz całkiem innego podejścia. W Europie to szczyt rozwoju ideologii kolonialnej, a zatem głębsze poznawanie muzułmańskiego Orientu to często wstęp do Saidowskiego „orientalizmu” (Said 2005). Arabowie zaś, dość naiwnie czasem zapatrzeni w rozwój technologii chcieli się czegoś nauczyć. I nie zawsze wyszło im to na dobre, jak pokazuje współczesność.

Podróże, te rzeczywiste i te duchowe od wielu lat są przedmiotem badań uczonych ze wszystkich dziedzin, stąd trudno w krótkim wprowadzeniu wskazać na wszystkie ważne, a nawet tylko najważniejsze aspekty tego zagadnienia, którego analiza wymaga interdyscyplinarnego podejścia - historycznego, antropologicznego, geograficznego, literaturoznawczego wreszcie. O tym wewnętrznym zróżnicowaniu świadczą zresztą teksty zawarte w tym tomie, ilustrujące niektóre wątki zaznaczone na poniższych stronach.

Marek M. Dziekan, Magdalena Lewicka

\section{Bibliografia}

Bieniek, Adam 2002. „Zakariyā’ Ibn Muḥammad Ibn Mahmūd al-Qazwīnī and his Works”, Folia Orientalia XXXVIII: 29-40.

Daniel 2003. Ihumena Daniela z ziemi ruskiej pielgrzymka do Ziemi Świętej (Relacja z początku XII wieku). Tłum. Krzysztof Pietkiewicz. Poznań: Wydawnictwo Poznańskie.

Dziekan, Marek M. 2012. „Choć się nie znamy, znamy się od dawna. O niektórych epizodach z dziejów kontaktów międzykulturowych Europy Środkowej i Bliskiego Wschodu". W: Robert Kusek, Joanna Sanetra-Szeliga (red.). Czy Polska leży nad Morzem Śródziemnym? / Does Poland lie on the Mediterranean?. Kraków: Międzynarodowe Centrum Kultury.

Eteria 1970. Pielgrzymka do miejsc świętych. Tłum. Władysław Szołdrski. „Pisma Starochrześcijańskich Pisarzy" 6. Warszawa: Akademia Teologii Katolickiej.

Al-Ḡarnāțī, Abū Ḥāmid 2006. De Grenade à Bagdad. La relation de voyage d'Abū Hāmid al-Gharnātī (1080-1168) ou Al-mu'rib 'an ba'd 'adjā'ib al-Maghrib (Exposition claire de quelques merveilles de l'Occident). Traduction annotée de Jean-Charles Ducène. Paris: Harmattan.

Hammoudi, Abdellah 2008. Pielgrzymka do Mekki. Tłum. Katarzyna Pachniak. Warszawa: Wydawnictwo Akademickie Dialog.

Hauziński, Jerzy 1997. „Jerozolima: doczesna czy mistyczna stolica Regnum Davidicum średniowiecza”. W: Piotr Paszkiewicz, Tadeusz Zadrożny (red.). Jerozolima w kulturze europejskiej. Warszawa: Instytut Sztuki PAN.

Ibn Battuta 2008. Osobliwości miast i dziwy podróży 1325-1354. Tłum. Tadeusz Majda, Halina Natorf. Warszawa: Książka i Wiedza. 
Koran 1986. Tłum. Józef Bielawski. Warszawa: PWN.

Nerval, Gérard de 1967. Podróż na Wschód. Tłum. Jadwiga Dmochowska. Wybór i przedmowa Marcin Czerwiński. Warszawa: Czytelnik.

Podróże Jana z Mandeville 2013. Tłum. Bartosz Marcińczak. Wstęp i komentarz Bartosz Marcińczak, Jacek Sokolski. Wrocław: Oficyna Wydawnicza ATUT - Wrocławskie Wydawnictwo Oświatowe.

Przybylski, Ryszard 1982. Podróż Juliusz Stowackiego na Wschód. Kraków: Wydawnictwo Literackie.

Said, Edward 1991. Orientalizm. Tłum. Witold Kalinowski. Wstęp Zdzisław Żygulski jun. Warszawa: PIW.

- 2005. Orientalizm. Tłum. Monika Wyrwas-Wiśniewska. Poznań: Zysk i S-ka.

Słowacki, Juliusz 2009. Album rysunkowe z podróży na Wschód. Wstęp i opracowanie Ewa Grzęda. Wrocław: Ossolineum.

Zaborski, Andrzej 1998. Wspaniaty Świat Oceanu Indyjskiego Sulajmana Kupca, Abū Zajda as-Sìrāî̀ i Buzurga Ibn Šahrijāra. Od literatury faktu do przygody i fantastyki (IX-X w.). Kraków: Księgarnia Akademicka. 